\title{
Hemodynamic and hormonal actions of adrenomedullin
}

Department of Internal Medicine, Faculty of Medicine and Health Sciences, United Arab Emirates University, Al Ain, United Arab Emirates
M.G. Nicholls

\begin{abstract}
Correspondence
M.G. Nicholls
Department of Internal Medicine
Faculty of Medicine and
Health Sciences
UAE University
P.O. Box 17666
Al Ain
United Arab Emirates
Fax: + 971-3-767-2995
E-mail: gary.nicholls@uaeu.ac.ae
Presented at the V International
Symposium on Vasoactive Peptides,
Ouro Preto, MG, Brazil,
February 12-14, 2004.
. . . . . . . . . . . . . . . . . . . . .
Received April 22, 2004

Accepted May 27, 2004

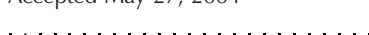

Abstract

Adrenomedullin, a 52-amino acid residue peptide, has numerous biological actions which are of potential importance to cardiovascular homeostasis, growth and development of cardiovascular tissues and bone, prevention of infection, and regulation of body fluid and electrolyte balance. Studies in man using intravenous infusion of the peptide have demonstrated that, at plasma levels detected after myocardial infarction or in heart failure, adrenomedullin reduces arterial pressure, increases heart rate and cardiac output, and activates the sympathetic and renin-angiotensin systems but suppresses aldosterone. The thresholds for these responses differ, being lower under some experimental circumstances for arterial pressure than for the other biological effects. Adrenomedullin administration inhibits the pressor and aldosterone-stimulating action of angiotensin II in man. By contrast, the pressor effect of norepinephrine is little altered by concomitant adrenomedullin administration. Although in the absence of a safe, specific antagonist of the actions of endogenous adrenomedullin it is difficult to be certain about the physiological and pathophysiological importance of this peptide in man, current evidence suggests that it serves to protect against cardiovascular overload and injury. Hope has been expressed that adrenomedullin or an agonist specific for adrenomedullin receptors might find a place in the treatment of cardiovascular disorders.
\end{abstract}

\section{Background}

Adrenomedullin is a 52-amino acid residue peptide which was isolated from human pheochromocytoma tissue by Kitamura and colleagues in 1993 (1). Not only did the ing the action of extracts from pheochromocytoma on platelet cAMP and describe its amino acid sequence, but they also determined its concentration in human plasma by radioimmunoassay and demonstrated its "rapid, strong (dose-related) and long lasting hypotensive effect" when administered as a authors isolate this new peptide by monitor-
Key words

- Adrenomedullin

- Hypertension

- Heart failure

- Aldosterone

- Renin

- Norepinephrine bolus intravenous injection to anesthetized rats. They surmised that adrenomedullin might be an important circulating hormone which participates in blood pressure control.

Eleven years later, much has been learned about this hormone. PubMed lists 1412 publications on adrenomedullin up to March 2004. Original articles, a book, book chapters, review papers, and conferences (held appropriately in Japan where much of the original work was performed) have been devoted to adrenomedullin and to the proadrenomedullin N-terminal 20-amino acid residue peptide (PAMP). 
In this review article, the effects of adrenomedullin on the cardiovascular system and vasoactive hormones will be discussed. Although the emphasis will be on studies carried out on man, results from some animal experiments, especially sheep, will be mentioned.

\section{Hemodynamic and hormone effects of adrenomedullin in healthy volunteers}

In an early study (2), short-term (3 h), low-dose ( 2 and $8 \mathrm{ng} \mathrm{kg}^{-1} \mathrm{~min}^{-1}$ or 0.4 and 1.5 pmol $\mathrm{kg}^{-1} \mathrm{~min}^{-1}$ ) intravenous infusion of adrenomedullin in healthy male volunteers reduced arterial pressure but had no effect on heart rate, plasma hormone levels (catecholamines, renin, aldosterone, cortisol, atrial or B-type natriuretic peptide) or urinary indices. Under the conditions of the cited study (single-blind, randomized, placebo-controlled, time-matched, with the volunteers on a dietary intake of $150 \mathrm{mmol} /$ day of sodium and $80 \mathrm{mmol} /$ day of potassium and in the sitting position), it was evident that the threshold for reducing arterial pressure was set lower than for altering heart rate, the neurohormones listed above, or urinary indices. Since the increase in venous levels of adrenomedullin during the higher of the two infusion rates was barely detectable (of the order of only $4 \mathrm{pmol} / \mathrm{l}$ ), it seemed that the peptide had an extremely potent effect on arterial pressure (2). This premise was confirmed by studies in which adrenomedullin increased forearm blood flow when infused directly into the brachial artery of healthy subjects at doses calculated to produce plasma levels similar to those reported in heart failure (3).

A subsequent study by Lainchbury et al. (4), also conducted on male volunteers, showed that higher doses of adrenomedullin (16 and $32 \mathrm{ng} \mathrm{kg}^{-1} \mathrm{~min}^{-1}$ for $2 \mathrm{~h}$ each), while again reducing arterial pressure, now increased heart rate by 10 beats per min and cardiac output by 4 liters per min. Similar observations were made by Del Bene et al. (5) who administered adrenomedullin intravenously at similar rates to healthy volunteers. Regarding neurohormones, Lainchbury et al. (4) reported that adrenomedullin stimulated a 2-fold rise in plasma renin and a $50 \%$ rise in circulating norepinephrine. Despite vigorous activation of the renin-angiotensin system, plasma aldosterone levels were unaltered, suggesting that adrenomedullin could inhibit the aldosterone response to angiotensin II, as had earlier studies on conscious sheep (6) and with dispersed rat adrenal zona glomerulosa cells $(7,8)$. Even at the higher rates of adrenomedullin infusion used in the study by Lainchbury et al. (4), urinary volume and sodium excretion were unchanged, indicating that the threshold for the hemodynamic and neurohormonal effects of adrenomedullin was set lower than for the renal effects. Again the caveat must be that different results might have been seen under different study conditions. For example in this second study by Lainchbury et al. (4), the healthy volunteers were on a restricted intake of dietary sodium ( $80 \mathrm{mmol} /$ day $)$ which, along with the fall in arterial pressure, might have served to obscure the urinary actions of infused adrenomedullin. Furthermore, manifestation of any renal actions of the peptide at these doses may require a more sustained period of infusion.

The results of the two studies by Lainchbury et al. $(2,4)$ contrast with those from the first report of adrenomedullin infusion in healthy volunteers in which Meeran and colleagues (9) reported that high infusion rates of the peptide (around $80 \mathrm{ng} \mathrm{kg}^{-1} \mathrm{~min}^{-1}$ ) were required to reduce arterial pressure. But interpretation of data from very brief (10 min) incremental infusions is difficult since any hypotensive action of the peptide at lower infusion rates might require more time to develop.

The contrasting effects of adrenomedullin on the renin-angiotensin system and on aldosterone observed in vitro, in animal and 
in human studies, were further investigated. Petrie and colleagues (10) observed that the aldosterone-stimulating action of a single infusion rate of angiotensin II, but not of ACTH, was attenuated by adrenomedullin (given intravenously at a rate of approximately $18 \mathrm{ng} \mathrm{kg}^{-1} \mathrm{~min}^{-1}$ ) in healthy volunteers. Troughton et al. (11), however, failed to show any inhibitory effect of adrenomedullin given at a dose similar to that used by Petrie and colleagues on the aldosteronestimulating action of an incremental infusion of angiotensin II (or ACTH) in healthy volunteers studied on a restricted sodium diet. They did note, however, that, under these experimental conditions, the pressor action of angiotensin II was attenuated by adrenomedullin, with the peak difference compared with a time-matched placebo infusion being approximately $5 / 3 \mathrm{mmHg}$ (11). Studies in sheep on a restricted sodium intake likewise showed that adrenomedullin infused at $33 \mathrm{ng} \mathrm{kg}^{-1} \mathrm{~min}^{-1}$ delayed and attenuated the pressor action of an incremental infusion of angiotensin II without altering the angiotensin II/aldosterone dose-response curve (12). Accordingly, one can conclude that, whereas there is no doubt that adrenomedullin can indeed inhibit the aldosterone secretory response to exogenous angiotensin II, under some experimental circumstances, the threshold for this effect is set higher than its inhibitory action against the pressor action of angiotensin II.

It is pertinent to inquire whether adrenomedullin inhibits the action of pressor hormones other than angiotensin II. Accordingly, Charles and colleagues (13) constructed angiotensin II/blood pressure and norepinephrine/blood pressure dose-response curves with background adrenomedullin (33 $\mathrm{ng} \mathrm{kg}^{-1} \mathrm{~min}^{-1}$ ) or matching nitroprusside infusions in healthy, conscious sheep. They again observed that adrenomedullin attenuated the angiotensin II/blood pressure dose-response, as also did nitroprusside. By contrast, whereas nitroprusside oblit- erated the pressor action of norepinephrine, adrenomedullin had no effect (Figure 1). Under the conditions of this study, adrenomedullin inhibited the aldosterone-stimulating effect of angiotensin II whereas, as might be expected, norepinephrine had no effect (Figure 1). It is apparent, therefore, that adrenomedullin is an inhibitor of both the pressor and aldosterone-stimulating actions of angiotensin II although the threshold for these effects differs with the experimental circumstances.

The selective blockade of the pressor action of angiotensin II by adrenomedullin was confirmed by Luodonpaa and colleagues (14). These investigators demonstrated that subcutaneous adrenomedullin administration inhibited the angiotensin II-induced rise in arterial pressure in conscious rats by $67 \%$ but had no effect on norepinephrine-induced hypertension. They further reported that the cardiac effects of angiotensin II (increased left ventricular ejection fraction and fractional shortening), but not of norepinephrine, were enhanced by adrenomedullin (14). Conversely, Cockcroft and colleagues (3) demonstrated that adrenomedullin antagonized the venoconstrictor effect of norepinephrine in healthy subjects. Thus, interactions (or lack thereof) between adrenomedullin and norepinephrine are vessel-specific.

In summary, the evidence available from studies on healthy volunteers is that adrenomedullin, infused at doses which increase its circulating concentrations to levels seen under pathophysiological circumstances (such as after acute myocardial infarction or in chronic heart failure), reduces arterial pressure, stimulates heart rate and cardiac output, and activates the renin-angiotensin and sympathetic systems. It can antagonize the pressor and aldosterone-secretory actions of angiotensin II but has little effect on the norepinephrine-induced rise in arterial pressure. However, antagonism of the venoconstrictor action of norepinephrine by adrenomedullin has been shown. 


\section{Hemodynamic and hormone effects of adrenomedullin in hypertensive patients}

Troughton and colleagues (15) infused adrenomedullin intravenously in 8 patients with essential hypertension in a protocol identical to that used previously in healthy volunteers (4). Results similar to those obtained for normotensive subjects were observed in that arterial pressure fell while heart rate and cardiac output increased as did plasma levels of renin and norepinephrine. Again, as observed in the healthy volunteers, plasma aldosterone levels were unaltered despite activation of the renin-angiotensin system. Also, the absence of any alteration in urinary volume and sodium excretion was

Figure 1. Arterial pressure and plasma aldosterone responses to incremental infusions of angiotensin II (A) and norepinephrine (B) during co-infusion with adrenomedullin $\left(33 \mathrm{ng} \mathrm{kg}^{-1} \mathrm{~min}^{-1}\right.$, triangles), nitroprusside (squares) or vehicle (control, circles) in eight healthy, conscious sheep (mean \pm SEM). Individual time points significantly different from time-matched data are indicated by *adrenomedullin versus control; ${ }^{+}$nitroprusside versus control; \#adrenomedullin versus nitroprusside (two-way ANOVA). Reproduced from Charles et al. (13), with permission.

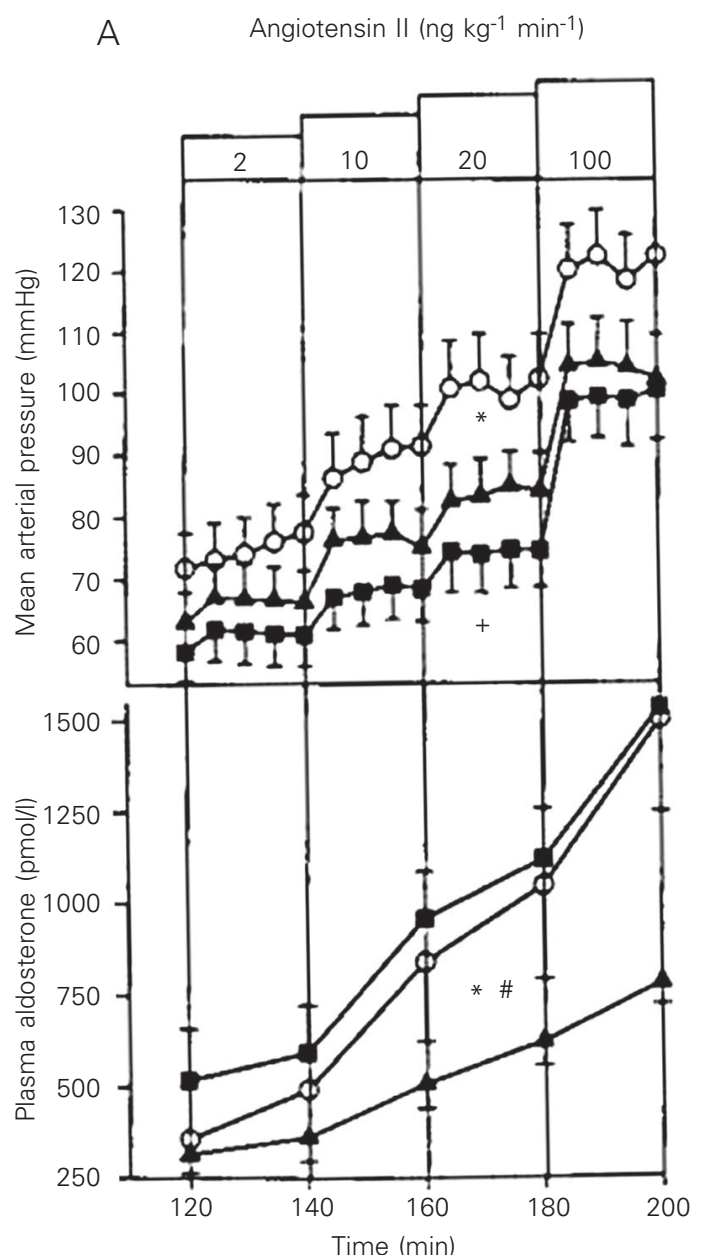

noted. The only differences in response to adrenomedullin between hypertensive and normotensive subjects were the increase in plasma epinephrine in the former but not the latter, the fact that the decline in arterial pressure was significantly greater (both in absolute and percentage terms) in hypertensive patients, and facial and conjunctival injection with or without headache was noted in 6 of the 8 patients with hypertension, but not in the normotensive subjects (15). It seems likely, therefore, that the arteriolar dilating action of adrenomedullin is more prominent in essential hypertension than in normotension. Some support for this contention comes from studies on rats with hypertension which showed greater absolute $(16,17)$ and percent $(18)$ declines in arterial

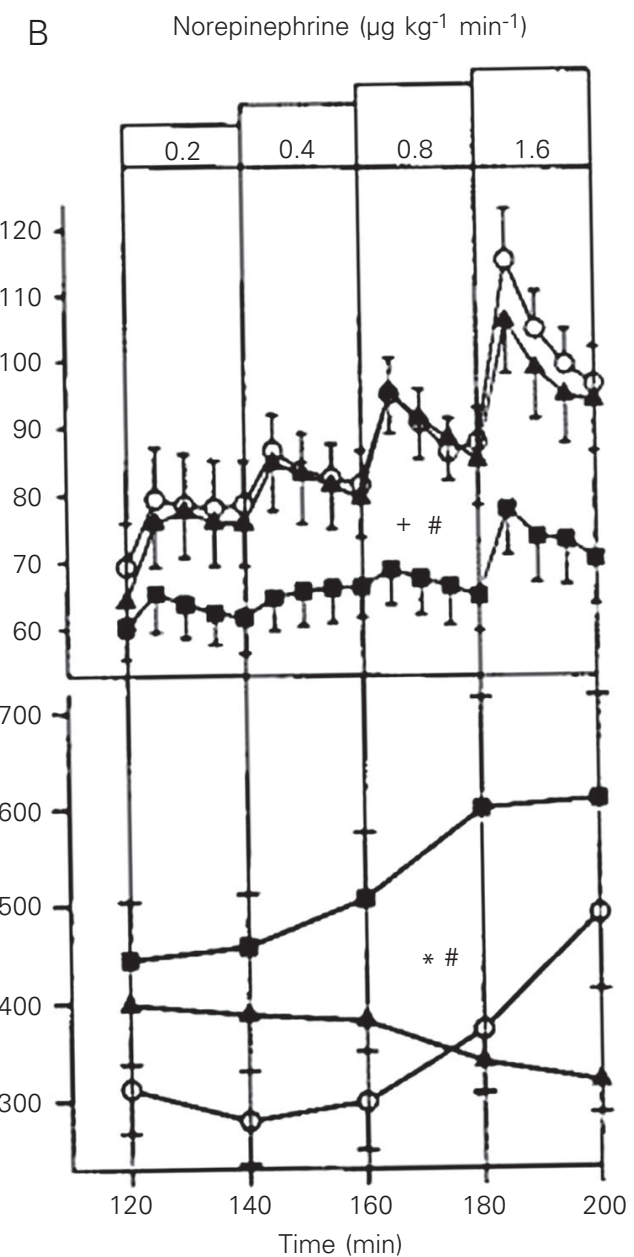


pressure than in normotensive control rats.

\section{Hemodynamic and hormone effects of adrenomedullin in patients with heart failure}

As reviewed by Rademaker et al. (19), numerous studies on experimental animals and humans have shown that plasma levels of immunoreactive adrenomedullin are increased in heart failure. Furthermore, adrenomedullin levels reflect the severity of cardiac impairment, are predictive of prognosis and may have a potential use by indicating which patients might benefit most from the addition of beta-blocker treatment (19).

Lainchbury et al. (20) infused adrenomedullin intravenously at approximately 14 and $28 \mathrm{ng} \mathrm{kg}^{-1} \mathrm{~min}^{-1}$, each for $2 \mathrm{~h}$, into 8 patients with chronic heart failure associated with a reduced left ventricular ejection fraction. Compared with a time-matched placebo infusion, adrenomedullin reduced arterial pressure, stimulated heart rate and plasma renin and norepinephrine levels, significantly suppressed plasma aldosterone, but had no effect on urine volume or sodium excretion (20). In contrast to the situation in healthy volunteers and patients with essential hypertension, cardiac output did not increase (20). Nagaya et al. (21) infused a much higher dose of adrenomedullin $\left(50 \mathrm{ng} \mathrm{kg}^{-1} \mathrm{~min}^{-1}\right)$ for 30 min into 7 patients with heart failure and reported a decline in arterial pressure and plasma aldosterone and an increase in heart rate. In contrast to the study of Lainchbury et al. (20), however, cardiac output increased as did urinary sodium excretion, but plasma renin levels were unchanged. Oya and colleagues (22) infused an even higher dose of the peptide (approximately $100 \mathrm{ng} \mathrm{kg}^{-1} \mathrm{~min}^{-1}$ ) over 30 min into 8 patients with heart failure and reported hemodynamic, hormonal and urinary effects similar to those observed by Nagaya et al. (21). That some of the hemodynamic effects are likely to be the result of arteriolar dilatation is suggested by Nakamura et al. (23) who demonstrated that adrenomedullin exerts a potent and sustained vasodilatory effect upon direct injection into the brachial artery of patients with cardiac failure. Interestingly, these effects, particularly on skin blood flow, were attenuated in patients with cardiac failure compared to healthy controls (23).

Adrenomedullin has been administered also to animals with experimental heart failure with usually beneficial hemodynamic, hormonal and renal effects (19). Accordingly, there has been speculation that this hormone, along with the cardiac natriuretic peptides and other vasodilator/natriuretic hormones, serves as a protector against cardiovascular involvement. Furthermore, the possibility has been raised that adrenomedullin, or an agent acting as an agonist on adrenomedullin receptors, might offer a new approach to the treatment of cardiac failure (24).

\section{Overview}

Whereas adrenomedullin has a plethora of biological actions (25), only its effects on hemodynamics and on vasoactive hormones have been discussed here, largely from studies on man. Even within this narrow focus a broad, rather than a detailed account is given. Largely ignored, for example, is a discussion regarding the effects of adrenomedullin on cardiac function, and the interaction between adrenomedullin and endothelin or the cardiac natriuretic peptides. Also not addressed is the potential for adrenomedullin to improve hemodynamic, hormone and renal indices in patients with chronic renal impairment (26) or to enhance the hemodynamic and clinical status of patients with pulmonary hypertension (27-29).

To summarize, the most obvious effects of adrenomedullin obtained by short-term intravenous infusion in healthy volunteers and in patients with essential hypertension or cardiac failure are a fall in arterial pres- 
sure, an increase in heart rate and cardiac output, activation of the sympathetic and renin-angiotensin systems without stimulation (or sometimes with suppression) of plasma aldosterone concentrations. Urine volume and sodium excretion are usually well maintained, or occasionally increased, despite the often substantial decline in renal artery perfusion pressure. Adrenomedullin can counter, to a greater or lesser extent, the pressor and aldosterone-secretory actions of angiotensin II. By contrast, the pressor activity of norepinephrine is little altered by adrenomedullin. Most of these biological effects may be viewed as beneficial in hyper- tension or cardiac failure. Such data have led to the premise that adrenomedullin may be protective against cardiac overload and cardiac and vascular damage (19,24,30-32). Furthermore, there has been speculation that when combined with, for example, blockade of the renin-angiotensin system (33) or enhancement of circulating levels of the cardiac natriuretic peptides (34), adrenomedullin or an adrenomedullin-receptor agonist might ultimately find a place in the therapeutics of circulatory disorders. Much more information on these issues can be expected in the near future.

\section{References}

1. Kitamura K, Kangawa K, Kawamoto M, Ichiki Y, Nakamura S, Matsuo H \& Eto $T$ (1993). Adrenomedullin: a novel hypotensive peptide isolated from human pheochromocytoma. Biochemical and Biophysical Research Communications, 192: 553-560.

2. Lainchbury JG, Cooper GJS, Coy DH, Jiang NY, Lewis LK, Yandle TG, Richards AM \& Nicholls MG (1997). Adrenomedullin: a hypotensive hormone in man. Clinical Science, 92: 467-472.

3. Cockcroft JR, Noon JP, Gardner-Medwin J \& Bennett T (1997). Haemodynamic effects of adrenomedullin in human resistance and capacitance vessels. British Journal of Clinical Pharmacology, 44: 57-60.

4. Lainchbury JG, Troughton RW, Lewis LK, Yandle TG, Richards AM \& Nicholls MG (2000). Hemodynamic, hormonal, and renal effects of short-term adrenomedullin infusion in healthy volunteers. Journal of Clinical Endocrinology and Metabolism, 85: 1016-1020.

5. Del Bene R, Lazzeri C, Barletta G, Vecchiarino S, Guerra CT, Franchi F \& La Villa G (2000). Effects of low-dose adrenomedullin on cardiac function and systemic haemodynamics in man. Clinical Physiology, 20: 457-465.

6. Charles CJ, Rademaker MT, Richards AM, Cooper GJS, Coy DH, Jing NY \& Nicholls MG (1997). Hemodynamic, hormonal, and renal effects of adrenomedullin in conscious sheep. American Journal of Physiology, 272: R2040-R2047.

7. Yamaguchi T, Baba K, Doi Y \& Yano K (1995). Effect of adrenomedullin on aldosterone secretion by dispersed rat adrenal zona glomerulosa cells. Life Sciences, 56: 379-387.

8. Andreis PG, Mazzocchi G, Rebuffat P \& Nussdorfer GG (1997). Effects of adrenomedullin and proadrenomedullin N-terminal 20 peptide on rat zona glomerulosa cells. Life Sciences, 60: 16931697.

9. Meeran K, O'Shea D, Upton PD, Small CJ, Ghatei MA, Byfield PH \& Bloom SR (1997). Circulating adrenomedullin does not regulate systemic blood pressure but increases plasma prolactin after intravenous infusion in humans: a pharmacokinetic study. Journal of Clinical Endocrinology and Metabolism, 82: 95-100.

10. Petrie MC, Hillier C, Morton JJ \& McMurray JJ (2000). Adrenomed- ullin selectively inhibits angiotensin II-induced aldosterone secretion in humans. Journal of Hypertension, 18: 61-64.

11. Troughton RW, Frampton CM, Lewis LK, Yandle TG, Richards AM \& Nicholls MG (2001). Differing thresholds for modulatory effects of adrenomedullin infusion on haemodynamic and hormone responses to angiotensin II and adrenocorticotrophic hormone in healthy volunteers. Clinical Science, 101: 103-109.

12. Charles CJ, Rademaker MT, Richards AM, Cooper GJ, Coy DH \& Nicholls MG (2000). Adrenomedullin attenuates pressor response to angiotensin II in conscious sheep. Journal of Cardiovascular Pharmacology, 36: 526-532.

13. Charles CJ, Nicholls MG, Rademaker MT \& Richards AM (2001). Comparative actions of adrenomedullin and nitroprusside: interactions with ANG II and norepinephrine. American Journal of Physiology, 281: R1887-R1894.

14. Luodonpaa $M$, Leskinen $H$, Ilves $M$, Vuolteenaho $O$ \& Ruskoaho $H$ (2004). Adrenomedullin modulates hemodynamic and cardiac effects of angiotensin II in conscious rats. American Journal of Physiology (in press).

15. Troughton RW, Lewis LK, Yandle TG, Richards AM \& Nicholls MG (2000). Hemodynamic, hormone, and urinary effects of adrenomedullin infusion in essential hypertension. Hypertension, 36: 588-593.

16. Khan Al, Kato J, Ishiyama Y, Kitamura K, Kangawa K \& Eto T (1997). Effect of chronically infused adrenomedullin in two-kidney, one-clip hypertensive rats. European Journal of Pharmacology, 333: 187190.

17. Khan Al, Kato J, Kitamura K, Kangawa K \& Eto T (1997). Hypotensive effect of chronically infused adrenomedullin in conscious WistarKyoto and spontaneously hypertensive rats. Clinical and Experimental Pharmacology and Physiology, 24: 139-142.

18. Tian Q, Zhao D, Tan DY et al. (1995). Vasodilator effect of human adrenomedullin(13-52) on hypertensive rats. Canadian Journal of Physiology and Pharmacology, 73: 1065-1069.

19. Rademaker MT, Cameron VA, Charles CJ, Lainchbury JG, Nicholls MG \& Richards AM (2003). Adrenomedullin and heart failure. Regulatory Peptides, 112: 51-60. 
20. Lainchbury JG, Nicholls MG, Espiner EA, Yandle TG, Lewis LK \& Richards AM (1999). Bioactivity and interactions of adrenomedullin and brain natriuretic peptide in patients with heart failure. Hypertension, 34: 70-75.

21. Nagaya N, Satoh T, Nishikimi T et al. (2000). Hemodynamic, renal, and hormonal effects of adrenomedullin infusion in patients with congestive heart failure. Circulation, 101: 498-503.

22. Oya H, Nagaya N, Furuichi S, Nishikimi T, Ueno K, Nakanishi N, Yamagishi M, Kangawa K \& Miyatake K (2000). Comparison of intravenous adrenomedullin with atrial natriuretic peptide in patients with congestive heart failure. American Journal of Cardiology, 86: 94-98.

23. Nakamura M, Yoshida $H$, Makita S, Arakawa N, Niinuma H \& Hiramori K (1997). Potent and long-lasting vasodilatory effects of adrenomedullin in humans. Comparisons between normal subjects and patients with chronic heart failure. Circulation, 95: 1214-1221.

24. Nishikimi T, Yoshihara F, Mori Y, Kangawa K \& Matsuoka H (2003). Cardioprotective effect of adrenomedullin in heart failure. Hypertension Research, 26 (Suppl): S121-S127.

25. Hinson JP, Kapas S \& Smith DM (2000). Adrenomedullin, a multifunctional regulatory peptide. Endocrine Reviews, 21: 138-167.

26. McGregor DO, Troughton RW, Frampton C, Lynn KL, Yandle T, Richards AM \& Nicholls MG (2001). Hypotensive and natriuretic actions of adrenomedullin in subjects with chronic renal impairment. Hypertension, 37: 1279-1284.

27. Nagaya N, Nishikimi T, Uematsu M et al. (2000). Haemodynamic and hormonal effects of adrenomedullin in patients with pulmonary hypertension. Heart, 84: 653-658.

28. Kandler MA, Von Der Hardt K, Mahfoud S, Chada M, Schoof E, Papadopoulos T, Rascher W \& Dotsch J (2003). Pilot intervention: aerosolized adrenomedullin reduces pulmonary hypertension. Journal of Pharmacology and Experimental Therapeutics, 306: 10211026 .

29. Nagaya N, Kyotani S, Uematsu M, Ueno K, Oya H, Nakanishi N, Shirai M, Mori H, Miyatake K \& Kangawa K (2004). Effects of adrenomedullin inhalation on hemodynamics and exercise capacity in patients with idiopathic pulmonary arterial hypertension. Circulation, 109: 351-356.

30. Kato K, Yin H, Agata J, Yoshida H, Chao L \& Chao J (2003). Adrenomedullin gene delivery attenuates myocardial infarction and apoptosis after ischemia and reperfusion. American Journal of Physiology, 285: H1506-H1514.

31. Nishikimi T, Yoshihara F, Horinaka S, Kobayashi N, Mori Y, Tadokoro K, Akimoto K, Minamino N, Kangawa K \& Matsuoka H (2003). Chronic administration of adrenomedullin attenuates transition from left ventricular hypertrophy to heart failure in rats. Hypertension, 42: 1034-1041.

32. Kawai J, Ando K, Tojo A, Shimosawa T, Takahashi K, Onozato ML, Yamasaki M, Ogita T, Nakaoka T \& Fujita T (2004). Endogenous adrenomedullin protects against vascular response to injury in mice. Circulation, 109: 1147-1153.

33. Rademaker MT, Charles CJ, Cooper GJ, Coy DH, Espiner EA, Lewis LK, Nicholls MG \& Richards AM (2002). Combined angiotensinconverting enzyme inhibition and adrenomedullin in an ovine model of heart failure. Clinical Science, 102: 653-660.

34. Rademaker MT, Charles CJ, Cooper GJS, Coy DH, Espiner EA, Lewis LK, Nicholls MG \& Richards AM (2002). Combined endopeptidase inhibition and adrenomedullin in sheep with experimental heart failure. Hypertension, 39: 93-98 